\section{Dissent disallowed in Singapore}

SIR-There exists an interesting juxtaposition of events in Singapore this week. On the one hand, scientists from all over the world are gathering for the Fourth Federation of Asian and Oceania Biochemists (FAOB) meeting, to present and discuss work freely. This meeting is important, as it is timely, to the powers that be in Singapore, in that it precedes the opening of the new Institute for Molecular and Cell Biology there, for which the talents of the international scientific community are being anxiously courted. In stark contrast, the voice of dissent in Singapore's parliament, Mr Joshua Jeyaretnam, is effectively silenced this week; together with the chairman of the opposition party, Mr Wong Hong Toy, he finds himself in the cells of Singapore's Changi Prison.

The history of events that have led to fines, imprisonment and the removal of the leader of the opposition from his seat in parliament is adequately dealt with in such publications as Time Magazine (8 September 1986), Financial Times (12 November 1986), Far Eastern Economic Review (4 September and 20 November 1986) and the Asian Wall Street Journal. As a result of these articles, in which the motives of the government and the independence of the judiciary are called into question, two of these publications have incurred sanctions. The net overall effect of these events is to suggest that the voice of dissent in Singapore, be it from individuals, editors or members of parliament, is to be silenced at any cost. It is against this political backdrop that the Singapore government, advised by a number of eminent scientists from the United Kingdom, the United States of America and West Germany, seeks aggressively to recruit internationally scientists upon whose cooperation the success of the FAOB meeting and that of the Institute for Molecular and Cell Biology rests.

This situation, taken as a whole, raises some quite difficult questions, addressed especially to those advising or considering working at the Institute for Molecular and Cell Biology in Singapore. When a scientist enters into a commitment of research in Singapore, does he retain his right to comment on what he sees? If the independence of the judiciary and the freedom of the press are called into question, who is left to take the responsibility of safeguarding the rights of the individual to criticize? This responsibility sometimes comes to rest in unexpected quarters. In this case, because their services are of value to the Singapore government, some of this responsibility lies squarely with the international scientific community. It is up to us to satisfy ourselves (the facts are on record) that the individual in Singapore who wishes to voice legitimate criticism has the freedom to do so. If this freedom does not prevail, then the scientific community at large, being in a position of influence, must not flinch from the responsibilities associated with this position, and must use this influence to foster the necessary change of attitude within the government in Singapore.

No government should assume that it can, through institutions such as the Institute for Molecular and Cell Biology in Singapore, exploit the talents of the international scientific community and expect the scientists concerned to turn a blind eye to the fate of the people in whose country they work.

London NW6, UK

Louis Mahadevan

\section{Fluoridation}

Sir-The 1983 Anglesey study ${ }^{1}$ does not demonstrate the effectiveness of fluoridation, as Francis B. Reed claims ${ }^{2}$. Apart from its questionable late selection of a known high-caries non-fluoridated control population different from that originally planned, without pre-fluoridation information on the populations being compared - making its "strictly blind conditions" worthless - its concluding assertion of "the universal finding that caries experience in a fluoridated community is consistently lower than in neighbouring non-floridated communities" is shown to be untrue by the many studies cited in Diesendorf's Commentary ${ }^{3}$. In New Zealand we have dental health figures for our entire child population, not just for samples as in "fluoridation trials". The figures for Auckland show that the children in the non-fluoridated part of the city require fewer fillings, not more ${ }^{4}$. The non-fluoridated off-shore island children also need fewer fillings, just like the fluoridated island of Anglesey.

John Colquhoun

Education Department,

University of Auckland,

Private Bag, Auckland,

New Zealand

Jackson, D. et al. Br. Dent. J. 138, 165-171 (1975); 158, 45-49 (1985)

Reed, F. B. Nature 323, 198 (1986)

Diesendorf, M. Nature 322, $125-129$ (1986)

4. Colquhoun, J. Community Dent. Oral Epidemiol. 13, 37-41 (1985).

\section{UK performance}

SIR-Your contributors have recently reviewed two influential reports on British performance in research ${ }^{1,2}$. One concludes that "the main findings are that in basic research in science as a whole, UK performance has deteriorated since the early 1970 s both in absolute terms and relative to other countries, notably FRG and
Japan". The figures that most strikingly emphasize this point are the citation rates.

This broadbrush conclusion disguises a more precise relationship. The relative proportions of each of the competitors' total research budgets spent on defence in the early 1980 s have respectively been 0.5 , 0.2 and 0.02 , demonstrating a clear negative correlation between the proportion of research funding for defence and the corresponding civil research performance.

One can only guess why this should be so, if indeed the relationship is real at all, let alone representative of the world at large, derived as it is from only three (very important) examples. Yet if it is real it smacks of a sort of logic: the greater the proportion spent on defence, the greater the number of defence scientists required to spend it and consequently, from a limited resource, the smaller the number in civil research; also the greater the proportion spent on defence, the greater is the restriction on research reports available for citation. The former points towards a real problem for UK civil research; the latter to a possible mitigating explanation of its apparent recent lacklustre performance.

Bureau of Applied Sciences,

Bruce Denness

Wydcombe Manor

Whitwell,

Isle of Wight PO38 2NY, UK

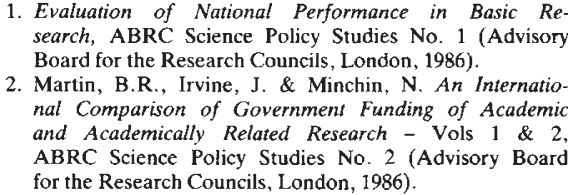
search, ABRC Science Policy Studies No. 1 (Advisory Board for the Research Councils, London, 1986).

2. Martin, B.R., Irvine, J. \& Minchin, N. An International Comparison of Government Funding of Academic and Academically Related Research - Vols 1 \& 2 ABRC Science Policy Studies No. 2 (Advisory Board for the Research Councils, London, 1986).

\section{Backfiring boycott}

SIR-The signatories of the Strategic Defense Initiative (SDI) boycott pledge (see Nature 323, 747; 1986) may find themselves in an embarrassing position, should the United States and the Soviet Union agree on how to regulate laboratory research on SDI. Would they recant their position, and on what grounds? The research programme (and that is all that the academics are involved in) will certainly not become technically any less dubious simply by receiving Mr Gorbachev's blessing. And were the Western scientists to continue their boycott unilaterally, they would simply be paving the way to a technological breakthrough by the Soviets, tempting them to break out from the AntiBallistic Missile Treaty. Is this course of action any less misguided than participation in SDI research? The most disturbing feature of the anti-SDI pledges circulating in the United States and now in Europe is that they are black-and-white statements that do not allow for any shades of grey.

686 Seneca Parkway, Nicholas Zumbulyadis

Rochester, New York 14613, USA 